\title{
Incorporating Geographic Information Science in the BSc Environ-mental Science Program in Botswana
}

\author{
Felicia O. Akinyemi ${ }^{\mathrm{a}}$ \\ ${ }^{a}$ Earth and Environmental Science Department, Faculty of Science, Botswana International University of Science and Technology, \\ Private Bag 16, Palapye, Botswana; felicia.akinyemi@gmail.com
}

\begin{abstract}
Critical human capacity in Geographic Information Science (GISc) is developed at the Botswana International University of Science and Technology, a specialized, research university. Strategies employed include GISc courses offered each semester to students from various programs, the conduct of field-based projects, enrolment in online courses, geo-spatial initiatives with external partners, and final year research projects utilizing geospatial technologies. A review is made of available GISc courses embedded in the Bachelor of Science Environmental Science program. GISc courses are incorporated in three Bachelor degree programs as distinct courses. Geospatial technologies are employed in several other courses. Student researches apply GIS and Remote Sensing methods to environmental and geological themes. The overarching goals are to equip students in various disciplines to utilize geospatial technologies, and enhance their spatial thinking and reasoning skills.
\end{abstract}

Keywords: Geographic Information Science, Geospatial technologies, Higher education, Research university, Spatial thinking, Spatial reasoning, Botswana

\section{Introduction}

Geospatial information and technologies are increasingly adopted in various fields. The possession of spatial thinking and reasoning skills is critical as such skills are integral to everyday life. Understanding these technologies and spatial thinking is increasingly vital to contemporary life, including common activities and hobbies; learning in science, mathematics, and social science; and employment within fields as diverse as engineering, health, business and planning (Nielsen et al. 2011). According to the National Research Council (2006, 5):

People, natural objects, human-made objects, and human-made structures exist somewhere in space, and the interactions of people and things must be understood in terms of locations, distances, directions, shapes, and patterns.

Kozak et al. (2008) described the integration of GISbased environmental data in evolutionary biology. Durr and Gatrell (2004) edited a volume on the application of GIS and spatial analysis in veterinary science. This widespread adoption of geospatial technologies increases the demand for geospatially skilled personnel (Ramli et al. 2010). Though the context of application might differ, the consensus is that there is a lack of skilled geospatial manpower in several countries (Akinyemi 2014). Training and education in the spatial sciences is an imperative for attaining the sustainable development goals (United Nations 2015, Choi et al. 2016).

Over the years, educational and training programs at different levels have emerged worldwide to meet this huge demand for geospatial specialists. Kerski (2015) examined opportunities in utilizing geospatial technologies in education. Other studies focused on the roles of GIS in higher education (Sinton 2009, Songer
2010, McMaster and Robert McMaster 2012, Lukinbeal and Monk 2015, Bearman et al. 2016). Eksteen et al. (2015) conducted a comparative study of GISc modules and degree programs in African and Latin American Universities. They found that there are more universities per country in Latin America than in Africa. Moreover, there is one university with Geographic Information Science (GISc) education for every 6 million people in Africa, whereas there is one for every 3.6 million people in Latin America. From the perspective of secondary education, the use of geospatial information and technologies was introduced in schools in different parts of the world since the 1980s (Lam et al. 2009, Kerski et al. 2013, Akinyemi 2014). Akinyemi (2015, 2016) assessed GIS use for teaching in Rwandan secondary schools. At the primary school level, studies have shown the necessity to enhance students' spatial reasoning skills (Davis and the Spatial reasoning Study Group 2015, Azevedo et al. 2016). With the aim of developing human capacity in GISc, different trajectories are taken in program design and development in higher education. For example, an examination of available educational and training programs in higher education reveals that GISc courses are either focused on teaching about or teaching with geographic information and technologies. Most of these courses are offered as part of undergraduate or postgraduate programs in various fields (Akinyemi 2012, Eksteen et al. 2015).

This paper describes the development of human capital in GISc and technologies within the educational programs of the Botswana International University of Science and Technology (BIUST), specifically in Environmental Science (ENVS). The paper outline is as follows: a brief background is given about available Bachelor GISc courses in BIUST. It describes various strategies 
employed in developing critical human capacity in GISc. Some student research applying GIS and Remote Sensing methods are also presented. The study contributes to ongoing efforts assessing the availability of GISc courses in developing countries.

\section{Background}

BIUST is a specialized, research university in Botswana. Having started its operations in 2012, it was established to provide an array of services in higher education in Science, Engineering and Technology - and applied research in an environment that fosters problem-based learning, discovery, creativity, and community engagement. The university seeks to stimulate local, national and regional economic development through the fulfilment of its mandate. This com-prise teaching and learning through training and education, research (basic and applied), and community service through engagement. It provides excellent research based academic programs, quality teaching and learning experience to students (BIUST 2016). At BIUST, research is intended to be an integral part of student learning that feeds into training and education as well as service to the community. Figure 1 shows that critical human capacity in GISc and technologies is built according to the three pillars of BIUST's mandate.

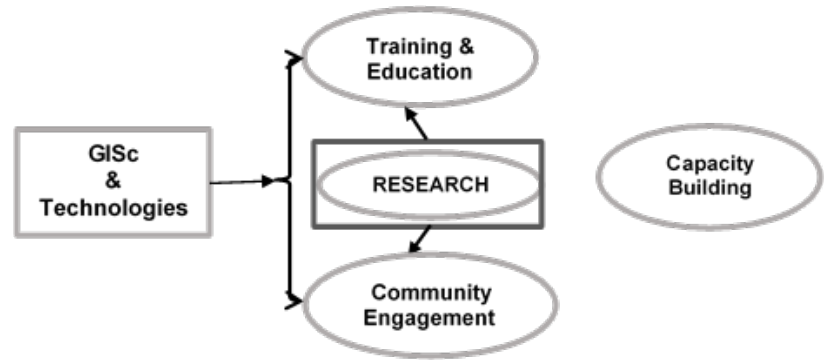

Fig.1. Building capacity in GISc and technologies in BIUST

GISc courses are embedded and taught as part of undergraduate and/or postgraduate programs. This study focuses only on undergraduate programs as these are well underway with the first cohort having graduated in 2016. Under-graduate programs with GISc courses as core or electives are Bachelor of Science (BSc) Environmental Science, BSc Earth and Environmental Science (EES), BSc Geology, and Bachelor of Engineering (BEng) Geological Engineering (GeoEng). All four undergraduate programs currently run for 8 semesters over a 4-year period except the BEng which currently runs for 10 semesters over a 5 -year period. As a relatively young university, these four Bachelor programs commenced at different times; BSc Geology, BSc EES and BEng GeoEng commenced in 2012, whereas BSc Environ-mental Science commenced in 2014.

\subsection{Structure of the BSc Environmental Science program}

Only the BSc Environmental Science (ENVS) program is described as all GISc courses are housed within this program. The first year aims to strengthen the science foundation of students by offering courses in mathematics, statistics, biology, chemistry, computer science and physics. By design, all first year programs in BIUST start with these science foundation courses. Students are introduced to environmental science in year two, as well as further grounding in physics, chemistry, mathematics, and statistics. Year three and four are almost entirely focused on environmental science courses with possibilities of electives from other undergraduate programs and a mandatory final research-based project. Students in the ENVS program also take a range of courses in entrepreneurial studies and technical writing.

\section{Developing Human Capacity in GISc}

Various methods employed in developing human capacity in GISc at BIUST include semester based courses, con-ducting field based projects incorporating students, enrolment in online GIS courses, geospatial information and technology initiatives with external partners, and research-based final year projects.

\subsection{Embedded GISc courses in the ENVS program}

GISc courses are taught to undergraduate students from different disciplines. A key component of teaching and learning in the ENVS program is the incorporation of GIS and Remote Sensing courses. The use of geospatial technologies are also taught in several other courses. Graduates of our programs possess geospatial skills, skills required by industry and/or governmental institutions in the 21st century (Walden University 2010, Qian and Clark 2016, Shin et al. 2016). These GISc courses are taught for 12 weeks during a semester (Table $1)$.

\begin{tabular}{|c|c|c|c|c|c|}
\hline $\begin{array}{l}\text { Course } \\
\text { code \& title }\end{array}$ & Programs Offering & $\begin{array}{l}\text { C } \\
\text { re } \\
\text { di } \\
\text { t }\end{array}$ & $\begin{array}{l}\text { Lev } \\
\text { el/ } \\
\text { Se } \\
\text { mes } \\
\text { ter }\end{array}$ & Type & $\begin{array}{l}\text { Pre- } \\
\text { requis } \\
\text { ite }\end{array}$ \\
\hline $\begin{array}{l}\text { ENVS 305: } \\
\text { Geographic } \\
\text { Information } \\
\text { Systems and } \\
\text { Databases }\end{array}$ & $\begin{array}{l}\text { BSc Geology, BSc } \\
\text { Environmental } \\
\text { Science, BSc Earth \& } \\
\text { Environmental } \\
\text { Sciences }\end{array}$ & 3 & $\begin{array}{l}300 \\
\text { leve } \\
1 / 1\end{array}$ & Core & none \\
\hline $\begin{array}{l}\text { ENVS 302: } \\
\text { Remote } \\
\text { Sensing in } \\
\text { Earth and } \\
\text { Environmen } \\
\text { tal Sciences }\end{array}$ & $\begin{array}{l}\text { BSc Geology, BSc } \\
\text { Environmental } \\
\text { Science, BSc Earth \& } \\
\text { Environmental } \\
\text { Sciences }\end{array}$ & 3 & $\begin{array}{l}300 \\
\text { leve } \\
1 / 2\end{array}$ & Core & $\begin{array}{l}\text { ENVS } \\
305\end{array}$ \\
\hline $\begin{array}{l}\text { ENVS 404: } \\
\text { Applied } \\
\text { Geographic } \\
\text { Information } \\
\text { System \& } \\
\text { Remote } \\
\text { Sensing }\end{array}$ & $\begin{array}{l}\text { BSc Environmental } \\
\text { Science }\end{array}$ & 3 & $\begin{array}{l}400 \\
\text { leve } \\
1 / 2\end{array}$ & $\begin{array}{l}\text { Core/ } \\
\text { Electi } \\
\text { ve }\end{array}$ & $\begin{array}{l}\text { ENVS } \\
302, \\
\text { ENVS } \\
305\end{array}$ \\
\hline
\end{tabular}

Source: author's compilation.

\section{Table 1. GISc undergraduate courses at BIUST}

Time allotted each week include 1 hour which is used for lecture, i.e. for teaching theoretical aspects; a 3-hour 
laboratory session for developing hands-on and a 1-hour tutorial session where students discuss in groups, ask and answer questions. The ENVS 305 course outline for is shown in Table 2. Continuous assessments (CA) are over $40-50 \%$ for individual and/or group assignments, lab exercises and pre-exam with laboratory and theory aspects examined. End of semester examination is conducted to examine both practical and theory with some essay questions requiring critical thinking abilities of students. These GISc courses are offered to students in the various programs but only ENVS 302 and ENVS 305 are running as the ENVS program has students currently only up to year three.

\begin{tabular}{|c|c|c|c|}
\hline $\begin{array}{l}\mathbf{W} \\
\mathbf{e}\end{array}$ & $\begin{array}{l}\text { Lecture } \\
\text { Topics }\end{array}$ & Labs & Exercises \\
\hline 1 & $\begin{array}{l}\text { General } \\
\text { overview of } \\
\text { GIS }\end{array}$ & $\begin{array}{l}\text { Lab \#1 Overview of } \\
\text { GIS functions/tools }\end{array}$ & $\begin{array}{l}\text { Exercise 1: } \\
\text { Creating an } \\
\text { administrati } \\
\text { ve map of } \\
\text { Botswana }\end{array}$ \\
\hline $\begin{array}{l}2 \\
\&\end{array}$ & $\begin{array}{l}\text { Spatial data } \\
\text { representation } \\
1 \text { (spatial data } \\
\text { models and } \\
\text { data structures) }\end{array}$ & $\begin{array}{ll}\begin{array}{l}\text { Lab } \\
\text { types }\end{array} & \text { Spatial data } \\
\text { - } \quad \text { Identifying } & \\
& \text { geographic } \\
& \text { phenomena }\end{array}$ & $\begin{array}{l}\text { Exercise 2: } \\
\text { Identifying } \\
\text { geographic } \\
\text { phenomena } \\
\text { and data types }\end{array}$ \\
\hline $\begin{array}{l}4 \\
\&\end{array}$ & $\begin{array}{l}\text { Projections \& } \\
\text { coordinate } \\
\text { systems }\end{array}$ & $\begin{array}{l}\text { Lab \#3 Getting } \\
\text { started with GIS }\end{array}$ & \\
\hline $\begin{array}{l}6 \\
\&\end{array}$ & $\begin{array}{l}\text { Spatial } \\
\text { database } \\
\text { management }\end{array}$ & $\begin{array}{l}\begin{array}{l}\text { Lab \#4 Database } \\
\text { design } \\
\text { implementation } \\
\text { - }\end{array} \\
\text { Creating attribute } \\
\text { data } \\
\text { Creating/importin } \\
\text { g spreadsheet data } \\
\text { into GIS } \\
\text { - Joining and } \\
\text { relating tables }\end{array}$ & $\begin{array}{l}\text { Exercise } 3: \\
\text { Spatial } \\
\text { Database } \\
\text { Design for } \\
\text { applications }\end{array}$ \\
\hline 8 & $\begin{array}{l}\text { Data capture 1: } \\
\text { GIS data } \\
\text { sources }\end{array}$ & $\begin{array}{l}\text { Lab \#5 Capturing } \\
\text { spatial data } \\
\text { - } \quad \text { GPS data capture }\end{array}$ & $\begin{array}{ll}\text { Exercise } & 4: \\
\text { Onscreen } & \\
\text { digitizing } & \text { of }\end{array}$ \\
\hline 9 & \begin{tabular}{lr}
\multicolumn{2}{l}{ Data capture 2: } \\
GIS data \\
sources from \\
Remote \\
Sensing \\
images
\end{tabular} & $\begin{array}{l}\text { Lab \#6 Onscreen } \\
\text { digitizing } \\
\text { - } \quad \text { Creating and } \\
\text { editing shapefiles } \\
\text { - } \begin{array}{l}\text { On-screen } \\
\text { digitizing }\end{array}\end{array}$ & $\begin{array}{l}\text { entities using } \\
\text { high } \\
\text { resolution } \\
\text { image e.g. } \\
\text { Orthophotogr } \\
\text { aph of } \\
\text { Palapye. }\end{array}$ \\
\hline $\begin{array}{l}1 \\
0\end{array}$ & $\begin{array}{l}\text { Pre-exam } \\
\text { (Theory \& lab) }\end{array}$ & $\begin{array}{l}\text { Lab \#7 Spatial data } \\
\text { retrieval } \\
\text { - } \quad \text { Selecting features } \\
\text { by attributes and } \\
\text { location }\end{array}$ & \\
\hline $\begin{array}{l}1 \\
1\end{array}$ & $\begin{array}{lr}\text { Spatial data } \\
\text { query and } \\
\text { analysis } \\
\text { (vector } \\
\text { operations) }\end{array}$ & $\begin{array}{l}\text { Lab \#8 Capturing } \\
\text { features on Campus } \\
\text { with handheld GPS }\end{array}$ & $\begin{array}{l}\text { Project: } \\
\text { Getting } \\
\text { started with } \\
\text { GIS online } \\
\text { course. }\end{array}$ \\
\hline
\end{tabular}

\begin{tabular}{l|l|l|}
1 & $\begin{array}{l}\text { Spatial data } \\
\text { analysis } \\
\begin{array}{l}\text { Raster } \\
\text { operations) }\end{array}\end{array}$ & $\begin{array}{l}\text { Lab \#9 Introduction to } \\
\text { DGPS }\end{array}$
\end{tabular}

Table 2. GIS and Databases course outline

\subsection{Undergraduate final year research projects}

The conduct of research-based projects by undergraduates in their final year is another way to build human capacity in GISc (Table 3). An example of a remote sensing image data utilized by projects include the use of the Normalized Difference Vegetation Index, a proxy for vegetation cover and production, for evaluating deviation of the current sea-son from the normal vegetation condition in a time series. Another project utilized image data from the Advanced Spaceborne Thermal Emission and Reflection Radiometer (ASTER) TIR bands for geological mapping. Most projects with field work components utilize GPS in capturing location attributes, for example, where soil samples were collected.

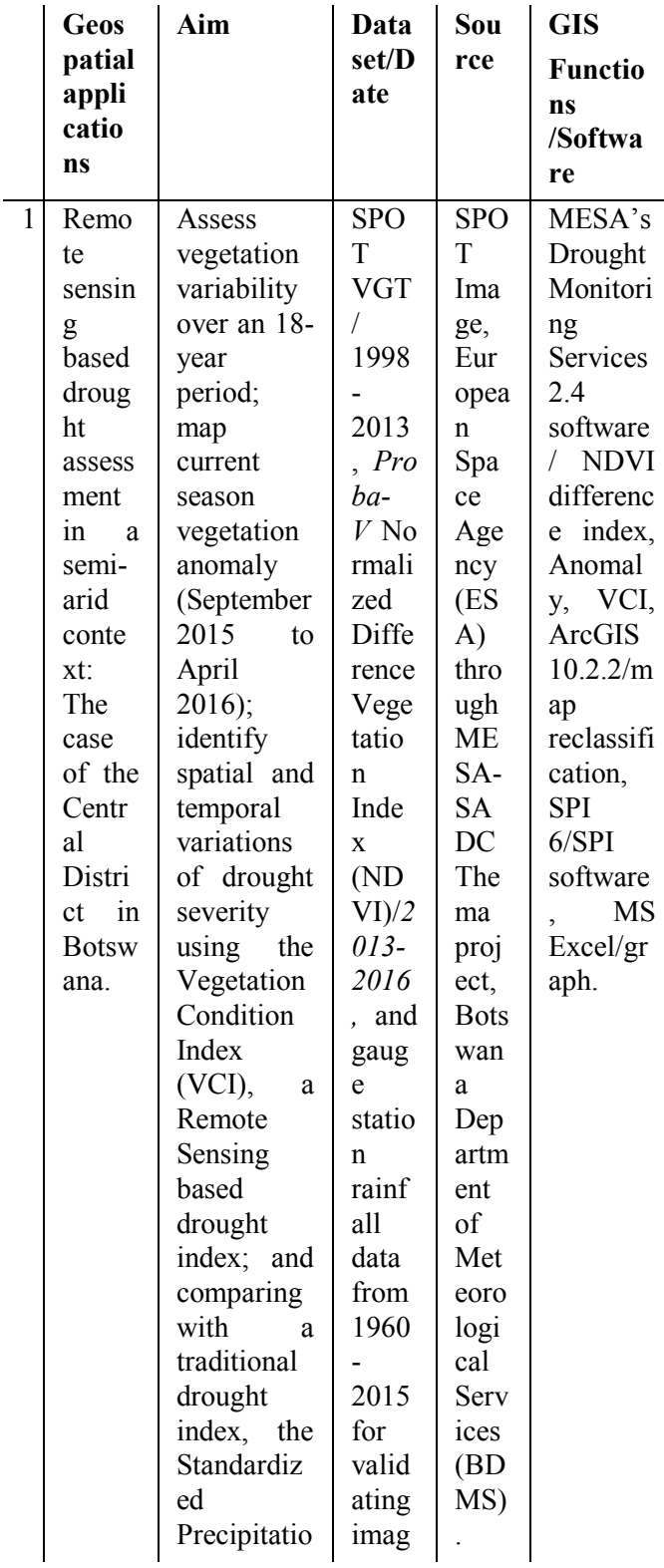




\begin{tabular}{|c|c|c|c|c|c|}
\hline & & $\begin{array}{l}\mathrm{n} \quad \text { Index } \\
\text { (SPI). }\end{array}$ & $\begin{array}{l}\text { e } \\
\text { analy } \\
\text { sis } \\
\text { prod } \\
\text { ucts. }\end{array}$ & & \\
\hline 2 & $\begin{array}{ll}\text { Landf } \\
\text { ill site } \\
\text { selecti } \\
\text { on } \\
\text { using } \\
\text { GIS - } \\
\text { Multi } \\
\text { Criter } \\
\text { ia } \\
\text { Analy } \\
\text { sis } \\
\text { based } \\
\text { appro } \\
\text { ach } \\
\text { for } \\
\text { Palap } \\
\text { ye } \\
\text { sub- } \\
\text { distric } \\
\text { t. }\end{array}$ & $\begin{array}{l}\text { Determine } \\
\text { suitable } \\
\text { sites for } \\
\text { locating a } \\
\text { landfill in } \\
\text { Palapye } \\
\text { sub-district } \\
\text { to } \\
\text { minimize } \\
\text { impacts on } \\
\text { the } \\
\text { environme } \\
\text { nt, human } \\
\text { health, and } \\
\text { tourism. }\end{array}$ & 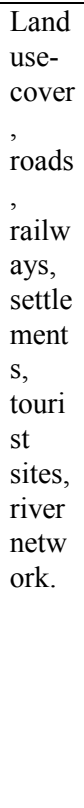 & $\begin{array}{l}\text { Bots } \\
\text { wan } \\
\text { a } \\
\text { Dep } \\
\text { artm } \\
\text { ent } \\
\text { of } \\
\text { Surv } \\
\text { ey } \\
\text { and } \\
\text { Map } \\
\text { ping }\end{array}$ & $\begin{array}{l}\text { ArcGIS } \\
10.2 .2 / \\
\text { Buffer, } \\
\text { Euclidia } \\
\mathrm{n} \\
\text { distance, } \\
\text { weighte } \\
\mathrm{d} \\
\text { overlay } \\
\text { analysis, } \\
\text { symboli } \\
\text { zation. It } \\
\text { utilizes } \\
\text { GIS } \\
\text { based } \\
\text { multi- } \\
\text { criteria } \\
\text { analysis } \\
\text { as } \\
\text { spatial } \\
\text { decision } \\
\text { support } \\
\text { tool. }\end{array}$ \\
\hline 3 & \begin{tabular}{|l} 
Franci \\
stown \\
region \\
geolo \\
gical \\
mappi \\
ng \\
using \\
ASTE \\
R and \\
aerom \\
agneti \\
c \\
data.
\end{tabular} & $\begin{array}{l}\text { Compariso } \\
\mathrm{n} \text { of image } \\
\text { data from } \\
\text { Advanced } \\
\text { Spaceborne } \\
\text { Thermal } \\
\text { Emission } \\
\text { and } \\
\text { Reflection } \\
\text { Radiometer } \\
\text { (ASTER) } \\
\text { sensor and } \\
\text { airborne } \\
\text { geomagneti } \\
\mathrm{c} \text { data for } \\
\text { geological } \\
\text { mapping of } \\
\text { the } \\
\text { Francistow } \\
\mathrm{n} \text { region. }\end{array}$ & $\begin{array}{l}\text { AST } \\
\text { ER } \\
\text { Leve } \\
\text { 1-1B } \\
\text { (L1B } \\
\text { ) } \\
\text { dayti } \\
\text { me } \\
\text { TIR } \\
\text { data } \\
\text { of } \\
\text { Janu } \\
\text { ary } \\
2015 \\
\text { and } \\
\text { direc } \\
\text { tiona } \\
1 \\
\text { cosin } \\
\text { e } \\
\text { filter } \\
\text { ed } \\
\text { Total } \\
\text { Mag } \\
\text { netic } \\
\text { Inten } \\
\text { sity } \\
\text { (TMI } \\
\text { ) } \\
\text { map } \\
\text { of } \\
1996\end{array}$ & $\begin{array}{l}\text { Geo } \\
\text { logi } \\
\text { cal } \\
\text { Surv } \\
\text { ey } \\
\text { of } \\
\text { Japa } \\
\text { n, } \\
\text { Adv } \\
\text { ance } \\
\text { d } \\
\text { Indu } \\
\text { stria } \\
\text { l } \\
\text { Scie } \\
\text { nce } \\
\text { and } \\
\text { Tec } \\
\text { hnol } \\
\text { ogy } \\
\text { MA } \\
\text { DA } \\
\text { S htt } \\
\text { ps:// } \\
\text { gba } \\
\text { nk.g } \\
\text { sj.jp } \\
\text { /ma } \\
\text { das/i } \\
\text { nde } \\
\text { x.ph } \\
\text { p?\#t } \\
\text { op, }\end{array}$ & $\begin{array}{l}\text { ArcGIS } \\
\text { 10.4/Ima } \\
\text { ge } \\
\text { analysis } \\
\text { tool, } \\
\text { Raster } \\
\text { calculato } \\
\text { r, NASA } \\
\text { rock } \\
\text { spectral } \\
\text { reflectan } \\
\text { ce } \\
\text { library, } \\
\text { MS } \\
\text { Excel/gr } \\
\text { aph, } \\
\text { Geosoft } \\
\text { /directio } \\
\text { nal } \\
\text { cosine } \\
\text { filter, } \\
\text { GPS for } \\
\text { coordina } \\
\text { tes of } \\
\text { rock } \\
\text { samples } \\
\text { collected } \\
\text { during } \\
\text { fieldwor } \\
\text { k. }\end{array}$ \\
\hline
\end{tabular}

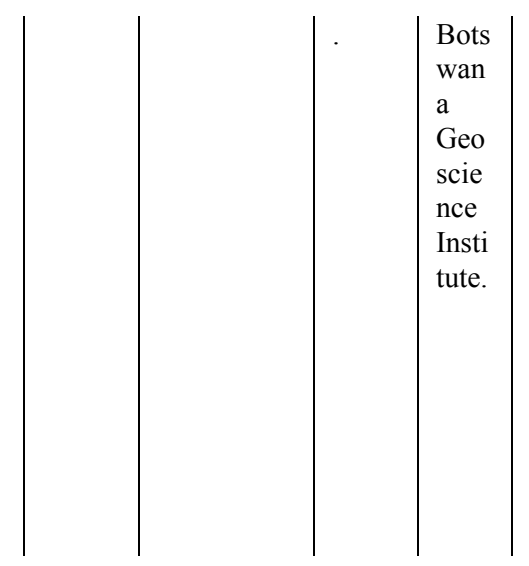

Source: author's compilation.

Table 3. Some examples of undergraduate student research projects conducted

\subsection{Field-based semester project}

Students undertake a field-based project during the ENVS 305 course that entails applying GIS and/or Remote Sensing techniques in any field. The goal is to aid student learning outside the classroom by applying geospatial technologies to solve problems in real world situations. One such project, titled "BIUST real estate (properties) information system" was conducted in 2015 over a 4-6 week period. With class sizes ranging from 38 to 112 students, the project is conducted as group assignment. Group work involved conducting an inventory of buildings and roads, digitizing buildings from images and GPS points (e.g., to create building outline), and spatial database design (conceptual, logical and physical) and implementation. Geotagged photographs of buildings and roads were also made. Identification codes for buildings and roads in BIUST were also developed (Table 4). The questionnaire used for building inventory is shown as Appendix 1. This project contributes to the spatial planning of the campus. Students learn to source and create spatial data, as well as databases for mapping purposes.

\begin{tabular}{|c|c|c|c|}
\hline ID & Name & Remarks & $\begin{array}{l}\text { Indicate } \\
\text { assigned } \\
\text { group }\end{array}$ \\
\hline B001 & Administrative block & & \\
\hline B002 & $\begin{array}{l}\text { Old College of Sciences } \\
\text { classrooms }\end{array}$ & & \\
\hline B003 & Hostel A & & \\
\hline B004 & Hostel B & & \\
\hline B005 & Hostel prefab & & \\
\hline B006 & Hostel SN & & \\
\hline B007 & Hostel Q & & \\
\hline B008 & Hostel SN1 & & \\
\hline B009 & Hostel Q1 & & \\
\hline B010 & Multi-purpose hall & & \\
\hline R001 & $\begin{array}{l}\text { North gate to campus } \\
\text { junction }\end{array}$ & $\begin{array}{l}\text { Tarred } \\
\text { road }\end{array}$ & \\
\hline R002 & Administration block to & Tarred & \\
\hline
\end{tabular}




\begin{tabular}{l|l|l|l} 
& waste water treatment plant & road & \\
\hline R003 & $\begin{array}{l}\text { Campus junction to south } \\
\text { gate }\end{array}$ & $\begin{array}{l}\text { Gravel } \\
\text { road }\end{array}$ & \\
\hline R004 & $\begin{array}{l}\text { Alternative road from north } \\
\text { gate to campus junction }\end{array}$ & $\begin{array}{l}\text { Gravel } \\
\text { road }\end{array}$ & \\
\hline R005 & Hostel junction to quarters & $\begin{array}{l}\text { Tarred } \\
\text { road }\end{array}$ & \\
\hline R006 & Quarters road & $\begin{array}{l}\text { Tarred } \\
\text { road }\end{array}$ & \\
\hline R007 & Senior quarters road & $\begin{array}{l}\text { Tarred } \\
\text { road }\end{array}$ &
\end{tabular}

Table 4. Identifier for buildings and roads in BIUST as of 2015

\subsection{Enrolment in the Environmental Systems Research Institute (ESRI) virtual campus online courses}

Students in the ENVS 305 course also enroll in the "Getting started with GIS" online course of the ESRI virtual cam-pus. The scope of the online course aligns with the preliminary topics covered in the earlier part of the semester. This is an opportunity for students to gain out-of-class experience in learning at their own pace using web-based technologies. For majority of the students, this was their experience with an online course. The possibility to earn an internationally recognized GIS certificate is an incentive which makes the ENVS 305 course attractive to students in BIUST. Upon successful completion of the online course, a certificate is obtained (see a sample in Figure 2). Upon submission of the certificate, grade for completing the online course is awarded to each student as a project component of the continous assessment.

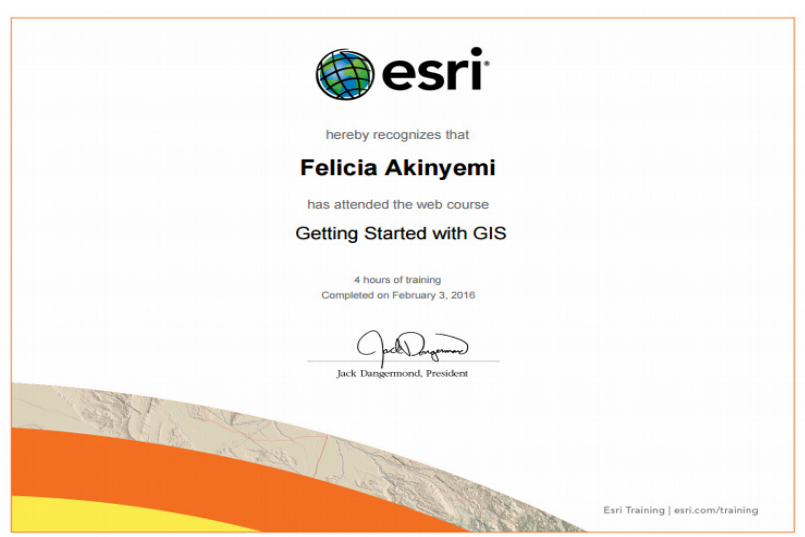

Fig. 2. A sample certificate obtained upon completion of the online course

\subsection{Monitoring for environment and security in} Africa Thema project (MESA)

The MESA project is implemented for the Southern African Development Community (SADC) with funds from the European Union and African Union. It commenced in 2013 with the goals of improving access to Earth Observation data, developing geospatial-based services on drought, agriculture, flood and wildfire. It develops expertise in geospatial technologies through regional and national trainings (Table 5). The project also provided BIUST as one of the beneficiary universities in the region with a receiving station (eStation) to access a variety of Earth Observation images through the EUMESAT (both archives and present) for use in teaching and research.

\begin{tabular}{|c|c|c|c|c|c|}
\hline & Training & $\begin{array}{l}\text { Sco } \\
\text { pe }\end{array}$ & Date & Participants & Location \\
\hline 1 & $\begin{array}{l}\text { Training of } \\
\text { trainers for } \\
\text { the } \\
\text { Agriculture } \\
\text { and Drought } \\
\text { Services }\end{array}$ & $\begin{array}{l}\text { Reg } \\
\text { ion } \\
\text { al }\end{array}$ & $\begin{array}{l}25 \\
\text { July- } \\
05 \\
\text { Aug } \\
\text { ust } \\
2016\end{array}$ & $\begin{array}{l}\text { National focal } \\
\text { persons } \\
\text { (NFPs) and } \\
\text { university } \\
\text { thematic } \\
\text { experts (TEs). }\end{array}$ & $\begin{array}{l}\text { Botswana } \\
\text { Universit } \\
\text { y of } \\
\text { Agricultu } \\
\text { re and } \\
\text { Natural } \\
\text { Resource } \\
\text { s } \\
\text { (BUAN) }\end{array}$ \\
\hline 2 & $\begin{array}{l}\text { Training of } \\
\text { Trainers for } \\
\text { the Flood } \\
\text { service }\end{array}$ & $\begin{array}{l}\text { Reg } \\
\text { ion } \\
\text { al }\end{array}$ & $\begin{array}{l}29 \\
\text { Aug } \\
\text { ust-9 } \\
\text { Sept. } \\
2016\end{array}$ & NFPs and TEs & $\begin{array}{l}\text { Universit } \\
\text { y of } \\
\text { Zimbabw } \\
\text { e (UoZ), } \\
\text { Harare }\end{array}$ \\
\hline 3 & $\begin{array}{l}\text { Workshop } \\
\text { for } \\
\text { beneficiary } \\
\text { universities } \\
\text { receiving } \\
\text { stations and } \\
\text { monitoring } \\
\text { services }\end{array}$ & $\begin{array}{l}\text { Reg } \\
\text { ion } \\
\text { al }\end{array}$ & $\begin{array}{l}14- \\
18 \\
\text { Marc } \\
\text { h } \\
2016 \\
\end{array}$ & $\begin{array}{l}\text { TEs and } \\
\text { system } \\
\text { administrator }\end{array}$ & $\begin{array}{l}\text { Namibia } \\
\text { Universit } \\
\mathrm{y} \text { of } \\
\text { Science } \\
\text { and } \\
\text { Technolo } \\
\text { gy, } \\
\text { Windhoe } \\
\mathrm{k}\end{array}$ \\
\hline 4 & $\begin{array}{l}\text { Training of } \\
\text { users (ToU) } \\
\text { on products } \\
\text { and services }\end{array}$ & $\begin{array}{l}\text { Nat } \\
\text { ion } \\
\text { al } \\
\text { Tra } \\
\text { inin } \\
\text { g } \\
\text { (N } \\
\text { TW } \\
\text { ) }\end{array}$ & $\begin{array}{l}5 \\
\text { Sept. } \\
-2 \\
\text { Dec. } \\
2016\end{array}$ & $\begin{array}{l}\text { 1-week } \\
\text { training was } \\
\text { hosted in each } \\
\text { of the } 15 \\
\text { countries in } \\
\text { SADC. }\end{array}$ & \\
\hline 5 & ToU & $\begin{array}{l}\text { Tan } \\
\text { zan } \\
\text { ia } \\
\text { NT } \\
\text { W }\end{array}$ & $\begin{array}{l}7-11 \\
\text { Sept. } \\
2015\end{array}$ & $\begin{array}{l}\text { Ministry of } \\
\text { Agriculture, } \\
\text { Food and } \\
\text { Cooperative, } \\
\text { Tanzania } \\
\text { Meteorologica } \\
1 \quad \text { Agency, } \\
\text { BDMS } \\
\text { (Meteorologic } \\
\text { al } \\
\text { services)/SAD } \\
\text { C-CSC, } \\
\text { Tanzania } \\
\text { Forestry } \\
\text { Research } \\
\text { Institute }\end{array}$ & $\begin{array}{l}\text { Dar es } \\
\text { Salaam, } \\
\text { Tanzania }\end{array}$ \\
\hline 6 & ToU & $\begin{array}{l}\text { Bot } \\
\text { swa } \\
\text { na } \\
\text { NT } \\
\text { W }\end{array}$ & $\begin{array}{l}10- \\
15 \\
\text { Aug } \\
\text { ust } \\
2015\end{array}$ & $\begin{array}{l}\text { BUAN, } \\
\text { Department of } \\
\text { Forestry and } \\
\text { Range } \\
\text { Resources, } \\
\text { BDMS/SADC } \\
\text {-CSC }\end{array}$ & $\begin{array}{l}\text { BIUST, } \\
\text { Palapye, } \\
\text { Botswana }\end{array}$ \\
\hline 7 & ToU & $\begin{array}{l}4 . \\
\text { Sou } \\
\text { th } \\
\text { Afr }\end{array}$ & $\begin{array}{l}5-7 \\
\text { Aug } \\
\text { ust } \\
2015\end{array}$ & $\begin{array}{l}\text { CSIR-Meraka } \\
\text { Institute, } \\
\text { Agric } \\
\text { Research }\end{array}$ & $\begin{array}{l}\text { South } \\
\text { Africa }\end{array}$ \\
\hline
\end{tabular}




\begin{tabular}{|c|c|c|c|c|c|}
\hline & & $\begin{array}{l}\text { ica } \\
\text { NT } \\
\text { W }\end{array}$ & & $\begin{array}{l}\text { Council, } \\
\text { BDMS/SADC } \\
\text {-CSC }\end{array}$ & \\
\hline 9 & ToU & $\begin{array}{l}\mathbf{5 .} \\
\text { Za } \\
\text { mbi } \\
\text { a } \\
\text { NT } \\
\text { W }\end{array}$ & $\begin{array}{l}27- \\
31 \\
\text { July } \\
2015\end{array}$ & $\begin{array}{l}\text { Environmental } \\
\text { Council of } \\
\text { Zambia, Land } \\
\text { Husbandry, } \\
\text { Zambia Meteo } \\
\text { Department }\end{array}$ & Zambia \\
\hline $\begin{array}{l}1 \\
1\end{array}$ & ToU & $\begin{array}{l}\text { 6. } \\
\mathrm{Zi} \\
\mathrm{mb} \\
\mathrm{ab} \\
\mathrm{we} \\
\mathrm{NT} \\
\mathrm{W}\end{array}$ & $\begin{array}{l}20- \\
24 \\
\text { July } \\
2015\end{array}$ & $\begin{array}{l}\text { National } \\
\text { Meteorologica } \\
1 \quad \text { Services, } \\
\text { Scientific and } \\
\text { Industrial } \\
\text { Research and } \\
\text { Development } \\
\text { Centre, } \\
\text { UoZ,BDMS/S } \\
\text { ADC-CSC }\end{array}$ & $\begin{array}{l}\text { Zimbabw } \\
\text { e }\end{array}$ \\
\hline
\end{tabular}

Source: author's compilation, from MESA-SADC website (http://www.mesasadc.org/)

Table 5. Selected MESA-SADC Thema training and workshop

\section{Conclusions}

GISc use in higher education is described from the perspective of a developing country context. Various strategies used in developing critical human capacity in Geographic Information Science (GISc) including utilizing geospatial technologies is discussed. GISc courses embedded in the Bachelor of Science Environmental Science program were re-viewed. With a strong research underpinning, students enrolled in these courses undertake research-based projects as individuals and in groups. Undergraduate students from various disciplines acquire the ability to utilize geospatial technologies, as well as develop their spatial thinking and reasoning skills. The role of web-based GIS online courses in enhancing student performance and outcome will be considered for future research.

\section{Appendix (optional)}

Building inventory questionnaire

No. of student survey group:

Date:

\begin{tabular}{l|l|l|l|l|}
$\mathbf{N}$ & Attri & Fill & Rem & $\bullet$ Meaning \\
$\mathbf{0}$ & bute & in & arks & \\
\hline
\end{tabular}

\section{- BUILDING IDENTIFICATION PROFILE}

\begin{tabular}{l|l|l|l|l}
\hline 1 & $\begin{array}{l}\text { B_Na } \\
\text { me }\end{array}$ & & & Name of building \\
\hline 2 & BID & & & $\begin{array}{l}\bullet \text { Building } \\
\text { identification }\end{array}$ \\
\hline 3 & x & & & $\bullet$ Coordinates \\
\hline 4 & y & & $\bullet$ Coordinates \\
\hline 5 & $\begin{array}{l}\text { Addr } \\
\text { ess }\end{array}$ & & $\begin{array}{l}\text { Street location of } \\
\text { building }\end{array}$
\end{tabular}

\begin{tabular}{|c|c|c|c|}
\hline 6 & Bno & & $\begin{array}{l}\text { Building Number, if } \\
\text { available }\end{array}$ \\
\hline 7 & $\begin{array}{l}\text { B_ty } \\
\text { pe }\end{array}$ & & $\begin{array}{l}\text { Building type e.g. } \\
\text { Storey } \text { building, } \\
\text { Detached house, } \\
\text { Bungalow, Duplex }\end{array}$ \\
\hline 8 & Use & & $\begin{array}{l}\text { Use to which building } \\
\text { is put e.g. residential, } \\
\text { administrative, } \\
\text { educational, religious, } \\
\text { refectory }\end{array}$ \\
\hline 9 & $\begin{array}{l}\text { Yr_C } \\
\text { om }\end{array}$ & & $\begin{array}{l}\text { Year building was } \\
\text { completed }\end{array}$ \\
\hline 10 & $\begin{array}{l}\text { Yr_In } \\
\text { aug }\end{array}$ & & $\begin{array}{l}\text { Year building was } \\
\text { inaugurated }\end{array}$ \\
\hline 11 & $\begin{array}{l}\text { Perso } \\
\mathrm{n}_{-} \\
\text {Inaug }\end{array}$ & & $\begin{array}{l}\text { Name of person that } \\
\text { inaugurated the } \\
\text { building }\end{array}$ \\
\hline 12 & $\begin{array}{l}\text { Fund } \\
\text { er }\end{array}$ & & $\begin{array}{l}\text { Name of donor, if } \\
\text { applicable }\end{array}$ \\
\hline 13 & Value & & The cost of building \\
\hline \multicolumn{4}{|c|}{$\begin{array}{l}\text { CAPACI } \\
\text { TY }\end{array}$} \\
\hline 14 & Size & & $\begin{array}{l}\text { Size of building in } \\
\text { Sq. metres }\end{array}$ \\
\hline 15 & $\begin{array}{l}\text { No_F } \\
\text { loor }\end{array}$ & & No. of floors \\
\hline 16 & $\begin{array}{l}\text { No_1 } \\
\text { abs }\end{array}$ & & No. of laboratories \\
\hline 17 & $\begin{array}{l}\text { No_c } \\
\text { lass }\end{array}$ & & $\begin{array}{l}\begin{array}{l}\text { Number } \\
\text { classrooms }\end{array} \quad \text { of } \\
\end{array}$ \\
\hline 18 & $\begin{array}{l}\text { No_o } \\
\text { ffice }\end{array}$ & & No. of office rooms \\
\hline 19 & $\begin{array}{l}\text { No } \\
\text { meeti } \\
\text { ng_ro } \\
\text { om }\end{array}$ & & $\begin{array}{l}\text { No. of conference } \\
\text { rooms }\end{array}$ \\
\hline \multicolumn{2}{|c|}{$\begin{array}{l}\text { AMENITI } \\
\text { ES }\end{array}$} & & \\
\hline 20 & $\begin{array}{l}\text { No_t } \\
\text { oilet }\end{array}$ & & No of toilets \\
\hline 21 & $\begin{array}{l}\text { No_b } \\
\text { ath }\end{array}$ & & No of bathrooms \\
\hline 22 & $\begin{array}{l}\text { Energ } \\
\mathrm{y}\end{array}$ & & $\begin{array}{l}\begin{array}{l}\text { Source of energy } \\
\text { (e.g., } \\
\text { generator, both etc.) }\end{array} \\
\end{array}$ \\
\hline 23 & $\begin{array}{l}\text { Eleva } \\
\text { tor }\end{array}$ & $\begin{array}{l}\mathrm{Ye} \\
\mathrm{s} \\
\text { No }\end{array}$ & $\begin{array}{l}\text { Is the elevator } \\
\text { functional? }\end{array}$ \\
\hline \multicolumn{2}{|c|}{$\begin{array}{l}\text { B_MATE } \\
\text { RIALS }\end{array}$} & & \\
\hline 24 & $\begin{array}{l}\text { Ceili } \\
\text { ng }\end{array}$ & & Material for ceiling \\
\hline 25 & Floor & & $\begin{array}{l}\text { Material for floor } \\
\text { (e.g., cemented, tiled, }\end{array}$ \\
\hline
\end{tabular}




\begin{tabular}{l|l|l|l|l} 
& & & & etc.) \\
\hline 26 & Wall & & $\begin{array}{l}\text { Material for walls } \\
\text { (e.g., } \\
\text { plastered, etc.) }\end{array}$ \\
\hline 27 & Paint & $\begin{array}{l}\text { Ye } \\
\text { s } \\
\text { No }\end{array}$ & & $\begin{array}{l}\text { Whether paints are } \\
\text { applied to walls. }\end{array}$ \\
\hline 28 & $\begin{array}{l}\text { Roofi } \\
\text { ng }\end{array}$ & & $\begin{array}{l}\text { Material for roofing } \\
\text { (e.g., Corrugated iron } \\
\text { sheets, cement, etc.) }\end{array}$
\end{tabular}

Any additional supporting data may be appended, provided the paper does not exceed the limits given above.

\section{References}

Akinyemi, F.O. (2012). Mainstreaming the use of geographic information in a developing country context: Examples from Rwanda. Pro-ceedings, Geo-Information Society of South Africa conference, October 3-5 2012, Guateng, South Africa. Available online at https://www.researchgate.net/publication/301526487_M ainstreaming_the_use_of_geographic_information_in_a _developing_country_context_examples_from_Rwanda

Akinyemi, F.O. (2014). Perspectives on developing critical GI human capacity in a developing country context. In Buchroithner, M., Prechtel, N. \& Burghardt D. (Eds.), Cartography from pole to pole (pp. 451-460). Berlin: Springer.

Akinyemi, F.O. (2015). An Assessment of GIS use for teaching in Rwandan secondary schools. The Geography Teacher, 12(1), 27-40. DOI:10.1080/19338341.2014.975144

Akinyemi, F.O. (2016). Technology use in Rwandan secondary schools: An assessment of teachers' attitudes towards geographic infor-mation systems (GIS). International Research in Geographical and Environmental Education, DOI:10.1080/10382046.2015.1106848

Azevedo, L., Ribeiro, V. \& Osório, A. (2016). Promoting a spatial perspective on primary students through geotechnologies. Proceed-ings, EDULEARN 16th Conference 4-6 July 2016, Barcelona, Spain, 64556459.

Bearman, N., Jones, N., André, I, Cachinho, H.C. \& DeMers, M. (2016). The future role of GIS education in creating critical spatial think-ers. Journal of Geography in Higher Education, 40(3), 394-408. DOI:10.1080/03098265.2016.1144729.

BIUST (2016). Strategic Plan-1 2016/17-2022/23: A catalyst for innovation and transformation. Palapye, Botswana: BIUST.

Choi J., Hwang, M., Kim, G., Seong, J., Ahn, J. (2016). Supporting the measurement of the United Nations' sustainable development goal 11 through the use of national urban information systems and open geospatial technologies: a case study of south Korea. Open Geo- spatial Data, Software and Standards 4 (1), Doi:10.1186/s40965-016-0005-0ID

Davis, B. and the Spatial Reasoning Study Group (2015). Spatial reasoning in the early years: Principles, assertions, and speculations. New York and London: Routledge.

Durr, P. \& Gatrell, A. eds. (2004). GIS and spatial analysis in veterinary science. Wallingford, Oxfordshire, UK: CABI Publishing, CAB International.

Eksteen, S., Coetzee, S., Lyew, M., Olivares, M., \& Solís, P. (2015). Geographic information science education at African and Latin American universities-A comparative review. Proceedings, 27th International Cartographic Conference, 23-28 August, 2015, Rio de Janeiro, Brazil. Available online

at http://www.icc2015.org/trabalhos/22/711/T22711_1426656422.docx

Kerski, J.J., Demirci, A., \& Milson, A.J. (2013). The global landscape of GIS in secondary education. Journal of Geography, 112, 232-247.

Kerski, J.J. (2015). Opportunities and challenges in using geospatial technologies for education. In Solari, O.M., Demirci, A. \& Schee, J. (Eds.), Geospatial Technologies and Geography Education in a Changing World (part V: pp 183-194), Japan: Springer. DOI:10.1007/978-4-43155519-3_15

Kozak, K.H., Graham, C.H. \& Wiens J.J. (2008). Integrating GIS-based environmental data into evolutionary biology. Trends in Ecology and Evolution, 30(10), 141-148. DOI:10.1016/j.tree.2008.02.001

Lam, C.C., Lai, E., \& Wong, J. (2009). Implementation of geographic information system in secondary geography curriculum in Hong Kong: Current situations and future directions. International Research in Geographical and Environmental Education, 18, 57-74.

Lukinbeal, C. \& Monk, J.J. (2015). Master's in geographic information systems programs in the United States: Professional education in GIS and Geography. The Professional Geographer, 67(3), 482-489. DOI:10.1080/00330124.2014.983630.

McMaster, S., \& McMaster, R. (2012). The university of Minnesota master of geographic information science (MGIS) program: A decade of experience in professional education. In Unwin, D., Foote, K., Tate, N., \& DiBiase, D. (Eds.), Teaching geographic information science and technology in higher education (pp.167-183), New York: Wiley-Blackwell.

National Research Council. (2006). Learning to think spatially: GIS as a support system in the $\mathrm{K}-12$ curriculum. Washington, D.C.: The National Academies Press.

Nielsen, C.P., Oberle, A. \& Sugumaran, R. (2011). Implementing a high school level geospatial technologies and spatial thinking course. Journal of Geography, 110(2), 60-69.

Qian, M., \& Clark K.R. (2016). Game-based learning and 21st century skills: A review of recent research. 
Computers in Human Behavior, 63, 50-58. DOI:10.1016/j.chb.2016.05.023.

Ramli, R., Noah, S.A. \& Yusof, M.M. (2010). Ontological-based model for human resource decision support system (HRDSS). Proceed-ings, Conference on the Move to Meaningful Internet Systems. 2529October, 2010, Crete, Greece.

Shin, E.E., Milson, A.J. \& Smith T.J. (2016). Future teachers' spatial thinking skills and attitudes. Journal of Geography, 115(4), 139-146. DOI:10.1080/00221341.2015.1100654

Sinton, D. (2009). Roles of GIS within higher education. Journal of Geography in Higher Education, 33 (supplemental 1), s7-s16.

Songer, L. (2010). Using web-based GIS in introductory human geography. Journal of Geography in Higher Education, 34(3), 401-417.

United Nations (2015). Transforming our world: The 2030 agenda for sustainable development. A/RES/70/1. Available https://sustainabledevelopment.un.org/content/document s/21252030\%20Agenda $\% 20$ for $\% 20$ Sustainable $\% 20 \mathrm{Dev}$ elopment $\% 20$ web.pdf

Walden University. (2010). Educators, technology and 21st century skills: Dispelling five myths. Report by Grunwald Associates LLC based on research by Eduventures, Inc. Available at http://www.grunwald.com/pdfs/Educators_Technology_ 21stCentury-Skills_GRUNWALD-

WALDEN_Report.pdf 